\title{
Development Finance and the 2030 Goals
}

\author{
Emma Mawdsley
}

\subsection{INTRODUCTION}

In August 2017, Achim Steiner, the recently appointed Administrator of the United Nations Development Programme (UNDP), addressed the annual conference of the European Association of Development Institutions, at Bergen, Norway. As the United Nation's (UN) leading development institution, the UNDP will play a particularly important role in pursuing the Sustainable Development Goals (SDGs) and the 2030 Agenda for Sustainable Development. Steiner was candid about some of the shortcomings of the SDGs, and he was all the more persuasive for that. His request to the large audience of international development academics and practitioners was that they actively, and critically, engage with the SDGs-whatever their faults, he argued, nothing better is going to come along.

In this short chapter, I pick up on one area that marks a key shift from the Millennium Development Goals (MDGs) and SDGs, namely financing. Accompanying the SDG process-their formulation, launch, and current operationalisation-has been a parallel set of multi-stakeholder meetings and debates over how to finance these hugely ambitious global goals, particularly in poorer countries. The slogan making the rounds is "from billions to trillions". Various forms of public and private finance were rallied for the MDGs (2000-2015), notably at the 2002 Monterrey Financing for Development conference. But the pre-eminent form of financing for the MDGs-and

\footnotetext{
E. Mawdsley $(\varangle)$

University of Cambridge, Cambridge, UK

e-mail: eem10@cam.ac.uk

(C) The Author(s) 2021 
thus attendant pressures and politics-was centred around official development assistance (ODA) or "foreign aid", including debt relief. A variety of MDG-related donor meetings sought to encourage donors to reach their longstanding commitments to provide 0.7 per cent of gross national income in ODA. Few have ever met this target (the annual number varies slightly, but it was five in 2018), and it seems most unlikely that the majority ever will, under current definitions and trends. As the SDGs coalesced, however, their ambition and scale evidently rendered this 0.7 per cent target grossly inadequate. ODA continues to be recognised as an important resource, especially for the poorest and/or most conflict-affected countries, but even if every donor met the 0.7 per cent target, it would barely touch the trillions that have been variously estimated to be required to achieve the SDGs. SDG 13 (Take urgent action to combat climate change and its impacts) is estimated to require $\$ 100$ billion annually by 2020 (Liverman 2018), while Schmidt-Traub (2015) calculates that an extra $\$ 1.4$ trillion a year is necessary to pursue all 17 goals in the lowand lower-middle-income countries alone.

Various sources of SDG finance are under discussion, such as raising levels of domestic resource mobilisation. Combating tax evasion and limiting capital flight, for example, were discussed at the 2015 UN summit on Financing for Development at Addis Ababa, but this failed to produce an international tax body, or indeed to bring any new money to the table. Rather, the energy lies with the private sector, and here the debates and initiatives around financing the 2030 Agenda are stimulating, deepening, and consolidating existing trends around the private sector within international development. Private-sector representatives are being invited to drive and shape global development governance and policy by the UN and other multilaterals (e.g. Mader 2016) and national development agencies (e.g. Mawdsley 2015). Despite referencing small and medium-sized enterprises, private-sector voices are dominantly from transnational corporations and the financial sector. In 2017, the Blended Finance Taskforce was established by the UN's Business \& Sustainable Development Commission to help mobilise this large-scale capital. In its flagship report, "Better Finance, Better World", produced in 2018, the task force aimed to identify key barriers to the effective use of blended finance and issued calls for action from leaders in the investment and development finance community (Blended Finance Taskforce 2018). Development institutions are increasingly seeking partnerships with venture capital, hedge funds, investment banks, sovereign wealth funds, credit rating agencies, global accountancy firms, and corporations, which are themselves increasingly governed by financial logics (Krippner 2011), in order to open up new circuits of financial investment, speculation, and extraction. The background against which this is happening is a shift away from the MDGs' focus on direct poverty reduction-however problematic that was-towards the central analytic of economic growth. 
The logic runs that, given the staggering amounts required to meet the projected investment gap-particularly, but not only, in poorer countries-the role of ODA and other forms of public finance should be to "unlock", "catalyse", and "leverage" much larger flows of private finance for "development". This is seen to be especially relevant to middle-income countries, which have broader borrowing choices and less need for ODA than low-income countries. Donors are increasingly deploying the concept of "blended finance" and expanding their use of financial instruments such as debt and equity finance for public-private partnerships (PPPs). Donors now actively promote one of their role's as “de-risking investment" through various guarantees and finance deals, or as Carroll and Jarvis (2014) put it, public money is being used to "escort international capital into frontier and emerging markets" in the name of development. The UN, the Organisation for Economic Co-operation and Development (OECD), Bretton Woods Institutions, and their privatesector partners all talk the language of sustainable growth ultimately serving poverty reduction-for example, of aligning the global financial system to "long-term" perspectives (when examined, "long term" can be as short as one year for investors); of building green economies and infrastructure; with labour (supposedly) protected by renewed commitments to corporate social responsibility.

Liverman (2018, p. 173) observes:

Rather than address the structural basis of poverty, hunger and inequality with roots in colonialism, the MDGs made developing countries responsible for addressing these problems, with a nod to the role of debt relief and aid in helping to meet the goals.

The failure to address the structural basis of poverty, inequality, and unsustainability is a criticism also made of the SDGs (Scheyvens et al. 2016), as weak accountability mechanisms favour existing models and vested interests (Donald and Way 2016). But it is the financing of the SDGs that is the focus here. The SDG "business model" is based on ever deeper integration and (supposed) alignment being projected between business, finance, development, and sustainability. But as Hickel (2015) observes, the SDGs seek to reduce inequality through income growth for the bottom 40 per cent, but without touching or redistributing the incomes of the top 1 per cent; SDG 17-to revitalise the global partnership for sustainable developmentincludes a target (17.10) that promotes universal open trading systems under the World Trade Organization and increasing exports from developing countries, for example. This is a model which has offered bare and highly precarious poverty reduction for some, and which has deepened global inequality.

The trend from the narrow construct of "ODA" to the broader category of "development finance" is not solely about the SDGs, but the 2030 Agenda provides a normalising narrative and, through the UN and other development organisations, the SDGs act as institutional interfaces for deepening 
state-private capital hybrid formations. This latest iteration of neoliberal development-in which the imperatives of finance play an even more prominent role than in earlier Washington and post-Washington Consensus ideologies and interventions - is expected to provide resources to scale, innovation, efficiency, and energy. The focus on infrastructure, land, and digital financial technologies (Gabor and Brooks 2017) are presented as essential drivers of growth, which will trickle down into poverty reduction. The growing turn towards state-supported development financing is not new, but it is certainly entering a different scale and phase. Donors and the mainstream international development community (now including Brazil, China, and India) are reorienting their narratives and practices to continue to serve capital, now in a qualitatively different conjuncture (Mawdsley 2015, 2018b). The "work" of the 1980s and 1990s (privatisation, land titling, deregulation, dismantling capital controls, and otherwise enhancing the free movement of capital) in the Global North and the Global South has led to vast over-accumulation of international capital, super-charged by booms and busts, including the 1997 Asian financial crisis, the 2001 dot com bubble, and the 2007/2008 global financial crisis. The "financing for development" agenda provides a legitimating veneer to the development industry's current "work" to create investment opportunities in "frontier" economies. In their analysis of the latest wave of donor-supported PPPs, for example, Bayliss and Van Waeyenberge (2018, p. 2) suggest:

While earlier drives for privatisation in donor advocacy formally highlighted the potential efficiency gains deriving from increased private sector involvement in public service provision, the more recent wave of PPP advocacy is anchored almost entirely in arguments seeking to match a glut in global savings with the need to upscale public service provision in developing countries. This has created an increasingly financialised approach to infrastructure, as policy is framed in terms of investment opportunities for financial investors and institutional arrangements bearing on infrastructure provision are reconfigured to facilitate their entry into the sector.

For its many mainstream advocates - the UN, bilateral development agencies, philanthrocapitalist foundations, and private-sector partners-this is entirely desirable. Greater "financial inclusion" for individuals and communities, and financial-sector deepening for low- and middle-income countries, are all framed as unalloyed improvements. A Kenyan woman can now safely transfer money to a distant relative or trading partner in the blink of an eye through M-Pesa, whereas at the other end of the spectrum, blended finance from Northern and Southern partners is leading to a surge of infrastructure building around the world. New approaches to impact investment (Organisation for Economic Co-operation and Development 2019) and new instruments such as development impact bonds and weather index-based insurance are deepening 
financial logics in development narratives, institutional functioning, programmatic interventions, and stakeholder subjectivities. Not all of these claims can be, or should be, lightly dismissed. But critical scholars are raising a host of concerns (e.g. Brooks 2016; Storm 2018). Out of what is an increasingly rich and detailed literature, two are very briefly mentioned here.

The first concerns complexity, accountability, and transparency. Efforts to monitor these flows of public money into private-sector and financial partnerships by academics and civil society watchdogs are increasingly hampered by commercial privacy barriers. For example, an increasingly large share of bilateral ODA is being routed through national development finance institutions, which are tasked with supplying investment to the private sector to support development in poor and middle-income countries. This can be in the form of loans, equity investments, risk guarantee instruments, and so on. Unlike more "traditional" uses of ODA, these flows now "leveraging" or "catalysing" private-sector investment can be hidden behind layers of commercial privacy, or in some cases routed through highly secretive tax havens (European Network on Debt and Development, n.d.). Even ODA is going to become more difficult to record and follow. The OECD-Development Assistance Committee (DAC) has been leading dialogue among its members around "modernising ODA". Although some desirable reforms appear to be emerging, it is evident that ODA will also become considerably more complex to understand and track. These trends have considerable implications for the transparency and accountability of public money, and also for scrutinising the claims that various public-private development partnerships are leading to the inclusive and sustainable growth claimed by the SDGs.

A second concern is that of risk. Over-indebted farmers committing suicide in India, housing bubbles in Argentina, and the enduring (and inherent) volatility of the global financial market are all forms and scales of risk that are largely unacknowledged in the ebullient language of "fintech" and financialsector deepening. Akyuz (2017) provides a searing critique of the growing risks of (over-)financialising the "periphery". At present, however, the international development community and its private-sector/financial partners appear to be complacent at best, and in denial at worst, about extending and deepening insufficiently regulated financial tools and markets. To take just one example, in 2017 the Business \& Sustainable Development Commission (which is an extremely high-ranking and influential platform launched in 2016 that was explicitly framed around the SDGs) produced a report on "Ideas for Action for a Long-Term and Sustainable Financial System" (Business \& Sustainable Development Commission 2017). The report's complacency about financialisation and risk is striking. Even as it seeks to better align the existing financial system with the aspirations of the SDGs, the report starts from the position that "global finance is highly regulated" (Business \& Sustainable Development Commission 2017, p. 7). The only reference to systemic risk is a reassuring statement on the "progress" made since the 2008 financial crisis. All remaining references to risk are couched in terms 
of risks to investors (e.g. because of climate change, or the higher risks of investing in poorer countries). The risks to borrowers or to collateral populations in contexts of deepening financialisation-whether individuals, municipal authorities, or countries-are almost entirely absent from the report. This is an extraordinary omission.

Steiner asked critical scholars to engage constructively with the SDGs, and there are persuasive reasons to do so. But the SDGs do not simply rest on a disastrous economic system, they seek to legitimate it, accelerate it, and deepen it. The global goals cannot resolve the contradictions between economies, societies, and environments-indeed, ecological survival-under the hegemony of finance capital.

\section{Note}

1. This chapter is adapted from a commentary on Liverman (2018) published in Dialogues in Human Geography (Mawdsley 2018a). I am grateful to the editors and publishers of $D H G$ for allowing me to publish it here with small amendments and adjustments; and to the editors and reviewers of this collection for their generosity and patience.

\section{REFERENCES}

Akyuz, Y. (2017). Playing with fire: Deepening financial integration and new vulnerabilities of the Global South. Oxford: Oxford University Press.

Bayliss, K., \& Van Waeyenberge, E. (2018). Unpacking the public-private partnership revival. The Journal of Development Studies, 54(4), 577-593.

Blended Finance Taskforce. (2018). Better finance, better world: Consultation paper of the blended finance taskforce. https://www.blendedfinance.earth/better-finance-bet ter-world.

Brooks, S. H. (2016). Private finance and the post-2015 development agenda. Development Finance Agenda, 1(3), 24-27.

Business \& Sustainable Development Commission. (2017). Ideas for action for a long-term and sustainable financial system. http://s3.amazonaws.com/aws-bsdc/ BSDC_SustainableFinanceSystem.pdf.

Carroll, T., \& Jarvis, D. S. L. (2014). Financialisation and development in Asia. London: Routledge.

Donald, K., \& Way, S. (2016). Accountability for the sustainable development goals: A lost opportunity? Ethics \& International Affairs, 30(2), 201-213. https://doi. org/10.1017/S0892679416000083.

European Network on Debt and Development. (n.d.). Private finance. https://eur odad.org/privatef.

Gabor, D., \& Brooks, S. H. (2017). The digital revolution in financial inclusion: International development in the fintech era. New Political Economy, 22(4), 423436.

Hickel, J. (2015, August 24). Why the new sustainable development goals won't make the world a fairer place. The Conversation. http://theconversation.com/whythe-new-sustainable-development-goals-wont-make-the-world-a-fairer-place- 46374 . 
Krippner, G. (2011). Capitalizing on crisis: The political origins of the rise of finance. Cambridge, MA: Harvard University Press.

Liverman, D. M. (2018). Geographic perspectives on development goals: Constructive engagements and critical perspectives on the MDGs and the SDGs. Dialogues in Human Geography, 8(2), 168-185.

Mader, P. (2016). Card crusaders, cash infidels and the holy grails of digital financial inclusion. Behemoth: A Journal on Civilisation, 9(2), 50-81. https://doi.org/10. 6094/behemoth.2016.9.2.916.

Mawdsley, E. (2015). DFID, the private sector, and the re-centring of an economic growth agenda in international development. Global Society, 29(3), 339-358.

Mawdsley, E. (2018a). "From billions to trillions": Financing the SDGs in a world "beyond aid". Dialogues in Human Geography, 8(2), 191-195.

Mawdsley, E. (2018b). The "Southernisation" of development? Asia Pacific Viewpoint, 59(2), 173-185.

Organisation for Economic Co-operation and Development. (2019). Social impact investment 2019: The impact imperative for sustainable development. https://www. oecd.org/dac/social-impact-investment-2019-9789264311299-en.htm.

Scheyvens, R., Banks, G., \& Hughes, E. (2016). The private sector and the SDGs: The need to move beyond "business as usual". Sustainable Development, 24(6), 371-382.

Schmidt-Traub, G. (2015). Investment needs to achieve the sustainable development goals: Understanding the billions and trillions. http://unsdsn.org/wp-content/upl oads /2015/09/151112-SDG-Financing-Needs.pdf.

Storm, S. (Ed.). (2018). Forum 2018. Development and Change, 49(2), 302-546.

Open Access This chapter is licensed under the terms of the Creative Commons Attribution 4.0 International License (http://creativecommons.org/licenses/by/4.0/), which permits use, sharing, adaptation, distribution and reproduction in any medium or format, as long as you give appropriate credit to the original author(s) and the source, provide a link to the Creative Commons license and indicate if changes were made.

The images or other third party material in this chapter are included in the chapter's Creative Commons license, unless indicated otherwise in a credit line to the material. If material is not included in the chapter's Creative Commons license and your intended use is not permitted by statutory regulation or exceeds the permitted use, you will need to obtain permission directly from the copyright holder.

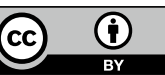

